\title{
FONEMIK BAHASA DAYAK MALI
}

\author{
Hotma Simanjuntak \\ FKIP Universitas Tanjungpura \\ Email: hotma.simanjuntak@fkip.untan.ac.id
}

\begin{abstract}
The Mali Dayak community resides in Balai-Batang Tarang Sub-district and a small part resides in Tayan Hilir District, Sanggau District. They have the same ethnic communication language, the Mali Dayak language. As of 2008 the number of Malian Dayak speakers was estimated at 6,963 people (Bamba, 2008). Languages with fewer than 10,000 speakers are classified as endangered (Crystal, 2000). If there is no attempt to maintain this Mali Dayak language, over time, this language is heading for extinction. Therefore, even the slightest effort to preserve this language needs to be done. This study discusses the main problems regarding the Dayak Mali phonemic, namely the determination of phonemes, allophones, phoneme distribution, phoneme groups (cluster), phoneme sequences, and syllables of the Dayak Mali language which are based on structural theory. The results of this study indicate the phonemes of the Dayak Mali language, namely vowel, diphthong, consonant, and semivocal phonemes. Based on its distribution, a phonemic allophon is apparent. The phonemic sequence also shows the environment of mutual influence and shows the symmetrical features of the phonemes found in the Dayak language of Mali. Similarly, the consonant group, the situation is answered through this research. The last problem examined is the syllables. The syllable structure contained in the Mali Dayak language is also described.
\end{abstract}

Keywords: Phoneme, Allophone, Cluster, Phoneme Sequences, Syllable

\section{PENDAHULUAN}

Penelitian ini merupakan kelanjutan dari tiga penelitian fonemik yang sudah berhasil dilakukan sebelum ini, yaitu Fonemik Bahasa Dayak Kenayatn (Simanjuntak, 2016) di Kabupaten Landak; Fonemik Bahasa Dayak Ulu Sakado (Simanjuntak, 2017) di Kabupaten Sekadau; dan Fonemik Bahasa Dayak Ketungau Sesat (Simanjuntak, 2018) di Kabupaten Sekadau. Selanjutnya, penelitian ini mengharapkan adanya pengungkapan Fonemik Bahasa Dayak Mali (BDM) di Kabupaten Sanggau.

Menurut Tata Bahasa Struktural bahasa terdiri atas dua lapisan, yaitu lapisan bentuk dan lapisan makna, atau arti (Bloomfield, 1933; Chomsky, 1946; O'Connor, 1973; Keraf, 1980; Ramlan, 1981, Samsuri, 1985; Parera, 1986; Crystal, 1987). Lapisan bentuk terdiri atas dua unsur, yaitu unsur segmental dan unsur suprasegmental. Unsur segmental ialah unsur yang berupa bagian-bagian yang dapat dipisahpisahkan atas bagian-bagian (segmen-segmen) yang lebih kecil. Unsur suprasegmental ialah unsur yang berada di luar unsur segmental, tetapi turut berperan menentukan makna yang terdapat di dalam unsur segmental itu, yaitu intonasi (tekanan, nada, durasi, dan jeda atau perhentian).

Berdasarkan lapisan bentuk dan lapisan makna tersebut bahasa dapat diteliti menurut cabangcabangnya, iaitu fonologi, morfologi, sintaksis, dan semantik. Penelitian ini akan membahas fonemik BDM. Alasan pemilihan cabang ini didasarkan pada pemikiran bahwa penelusuran bagian-bagian bahasa itu hendaknya dimulai dari bagian-bagian (segmen) yang terkecil. Selanjutnya penelitian dapat membahas bagian-bagian yang lebih besar lagi, misalnya, kata, frasa, klausa, dan atau kalimat. Pemilihan BDM juga didasarkan pada fakta bahawa $\mathrm{BDM}$ adalah bahasa daerah yang tergolong penting karena termasuk bahasa memerlukan pelestarian. Dilihat dari jumlah penuturnya, hanya sekitar 6.963 orang, yaitu bahasa yang terancam punah (Crystal, 2000). Subsuku Dayak Mali yang bermukim di Kecamatan Balai-Batang Tarang tersebar di 21 
kampung. Empat belas kampung berada dalam wilayah Kecamatan Balai-Batang Tarang dan tujuh kampung berada di wilayah Kecamatan Tayan Hilir, Kabupaten Sanggau, Kalimantan Barat.

Di dalam penelitian ini permasalahan dirinci sebagai berikut: penentuan fonem, alofon dan distribusi fonem, gugus fonem, deret Fonem, dan suku kata BDM. Tujuannya ialah untuk mendeskripsikan: fonem-fonem, alofon dan distribusi fonem, gugus fonem, deret fonem, dan suku kata.

Teori tata bahasa struktural menunjukkan bahwa bahasa haruslah dikenali dari hakikat bahasa itu sendiri. Salah satu hakikat bahasa itu ialah bunyi yang bersistem. Berdasarkan ada tidaknya hambatan atau rintangan terhadap arus udara oleh alat-alat ucap, bunyi bahasa dapat dibedakan menjadi dua kelompok: vokal dan konsonan. Menurut Crystal, 1987: 162) kualitas vokal ditentukan oleh tiga faktor, yang menjadi ciri pembedanya (distinctive features), yaitu: tinggi-rendahnya posisi lidah. Posisi lidah ada tiga macam: tinggi, sedang, dan rendah mengikut gerakan rahang bawah; bagian lidah (yang dinaikkan atau diturunkan, meliputi ujung lidah (lidah bagian depan), tengah lidah, dan pangkal lidah (lidah bagian belakang). Di samping posisi lidah dan bagian lidah yang digerakkan, kualitas vokal juga ditentukan oleh bentuk bibir, yaitu normal, melebar (terentang), dan bundar.

Berdasarkan ketiga faktor penentuan vokal, kita menyebut vokal /i/ sebagai vokal tinggi, depan, dan bibir melebar, sedangkan vokal /u/ sebagai vokal tinggi, belakang, dan bibir agak bundar. Identitas vokal /i/ dan /u/ ditunjukkan oleh dua ciri pembeda, yaitu /i/ sebagai vokal depan dan bentuk bibir belebar; sedangkan /u/ sebagai vokal belakang dan bibir agak bundar.

Diftong (vokal rangkap dua) adalah vokal yang berubah kualitasnya (Verhaar, 1981: 24-26). Dalam sistem tulisan diftong dilambangkan dengan dua huruf vokal. Kedua huruf vokal itu tidak dapat dipisahkan. Bunyi /aw/ pada kata harimau adalah diftong. Suku katanya terdiri dari ha-ri-maw. Demikian pula kata gulai (lauk yang disantan) suku kata terakhirnya lay adalah diftong. sedangkan kata gulai (beri gula) terdiri dari tiga suku kata: gu-la-i, suku terakhirnya adalah akhiran $-i$. Diftong berbeda dari deretan vokal. Tiap-tiap vokal pada deretan vokal termasuk dalam dua suku kata yang berbeda.

Yang kedua, bunyi konsonan adalah bunyi bahasa, yang terjadi oleh karena adanya halangan atau rintangan arus udara di dalam alat ucap tertentu yang dilaluinya. Pada pelafalan konsonan ada tiga faktor yang terlibat sebagai ciri pembeda konsonan (Crystal, 1987: 162): keadaan pita suara, titik artikulasi, dan cara artikulator bersentuhan atau berdekatan. Pita suara dapat merapat dan merenggang. Konsonan yang dilafalkan dengan pita suara merapat disebut konsonan bersuara, misalnya /b, d, j, g/, sedangkan konsonan yang dilafalkan dengan pita suara merenggang disebut konsonan tidak bersuara, misalnya /p, t, c, k/.

Titik artikulasi, iaitu penyentuhan atau pendekatan di antara artikulator. Titik artikulasi atas penyentuhan bibir atas dengan bibir bawah menghasilkan bunyi bilabial, gigi atas menyentuh bibir bawah menghasilkan bunyi labiodental, ujung lidah menyentuh gigi atas menghasilkan bunyi apikodental, ujung lidah menyentuh pangkal gigi atas (gusi) menghasilkan bunyi apikoalveolar, daun lidah menyentuh langit-langit keras menghasilkan bunyi laminopalatal, pangkal lidah menyentuh langit-langit lunak menghasilkan bunyi dorsovelar, dan apabila pita suara didekatkan cukup rapat sehingga arus udara dari paru-paru tertahan, maka bunyi yang akan terbentuk adalah bunyi glotal (hamzah). Berdasarkan cara artikulasi (cara alat ucap bersentuhan) ada beberapa macam bunyi bahasa yang dihasilkan. Bila udara dari paru-paru dihambat secara total, maka bunyi yang dihasilkan dinamakan bunyi hambat atau plosif. Apabila arus udara melalui saluran sempit, maka akan terdengar bunyi desis atau frikatif. Apabila ujung lidah bersentuhan dengan gusi dan udara keluar melalui samping lidah, maka bunyi yang dihasilkan dinamakan bunyi lateral. Jika ujung lidah menyentuh langit-langit keras, atau pangkal lidah menyentuh langit-langit lunak secara berulangulang, bunyi bahasa yang dihasilkan dinamakan bunyi getar atau tril.

Berdasarkan faktor-faktor di atas identitas fonem /p/ dikatakan sebagai fonem tak bersuara, bilabial, dan hambat (plosif). Sedangkan identitas fonem /b/ dikatakan sebagai fonem bersuara, bilabial, dan hambat (plosif). Ciri pembeda yang dimiliki kedua fonem itu terletak pada satu perbedaan: /b/ bersuara, sedangkan /p/ tak bersuara.

Ada juga konsonan yang dihasilkan sama seperti cara pembentukan vokal. Tetapi bunyi-bunyi ini tak pernah dapat menjadi inti suku kata (puncak). Yang termasuk kategori ini adalah bunyi /w/ yang mirip pembentukannya dengan /u/ dan bunyi /y/ yang mirip pembentukannya dengan /i/. 
Selain teori Ciri Pembeda, ada juga teori analisis fonem yang dikemukakan oleh para linguis sebagaimana tampak di dalam Samsuri (1985) yang menyatakan premis-premis dan hipotesis kerja, bahwa bunyi-bunyi bahasa yang secara fonetis mirip, harus digolongkan ke dalam kelas-kelas bunyi atau fonem-fonem yang berbeda, apabila terdapat pertentangan di dalam lingkungan yang sama atau mirip. Cara kerja ini dapat diterapkan melalui pasangan minimal. Pasangan minimal seperti [paku] dan [baku], [tari] dan [dari], [kali] dan [gali], [acar] dan [ajar], [keras] dan [kelas], [ajar] dan [ajal] dan sebagainya, menunjukkan dengan segera, bahwa bunyi-bunyi yang berbeda di dalam pasanganpasangan itu merupakan fonem yang berlainan, yaitu /p/ dan /b/, /t/ dan /d/, /c/ dan /j/, /k/ dan /g/, serta /r/ dan /1/. Kedua, bunyi-bunyi yang secara fonetis mirip dan terdapat di dalam distribusi yang komplementer, harus dimasukkan ke dalam kelas bunyi yang sama (fonem yang sama). Misalnya $/ \mathrm{p} /$ dalam bahasa Indonesia, mempunyai dua alofon, iaitu [p] terbuka yang terdapat pada awal kata atau suku kata dan [p'] tertutup yang terdapat pada akhir kata atau akhir suku kata.

Fonem suprasegmental sama saja cara penyelidikannya. Misalnya, tekanan (stress) boleh merupakan fonem. Dalam bahasa Batak Toba, bentuk [tógu] tekanan pada suku pertama, berarti menuntun, sedangkan bentuk [togú] tekanan pada suku kedua, artinya kuat. Oleh karena itu, tekanan dalam bahasa Batak Toba merupakan fonem. Demikian pula bentuk [bágas] artinya, rumah, sedangkan [bagás] artinya, dalam. Demikian pula nada, durasi, dan jeda.

Penentuan fonem selanjutnya ialah melihat distribusi fonem-fonem dalam kata: fonem apa saja yang dapat menempati posisi di awal kata, di tengah kata, dan di akhir kata; di awal dan di tengah kata saja; di tengah dan di akhir kata saja; dan di akhir kata saja; atau dalam suku kata (sebelum atau sesudah puncak; suku terbuka atau tertutup). Distribusi fonem dapat menimbulkan terjadinya alofon (variasi fonem). Fonem tersebut bervariasi karena berdistribusi komplementer. Bagi konsonan hambat, dapat menimbulkan dua alofon, yaitu terbuka (eksplosif) apabila terletak pada awal suku kata dan alofon tertutup (implosif) apabila terletak pada akhir suku kata. Demikian pula vokal /i/ dalam bahasa Indonesia, misalnya mempunyai dua alofon, yaitu [i] dan [I]. Fonem /i/ dilafalkan [i] jika terdapat pada (1) suku kata terbuka, atau (2) suku kata tertutup yang berakhir dengan fonem $/ \mathrm{m} /, / \mathrm{n} /$, atau $/ \mathrm{y} /$ dan mendapat aksen (tekanan) yang lebih berat daripada suku kata yang lain. Distribusi fonem /i/ terdapat di awal, tengah, dan akhir kata.

Gugus fonem adalah deretan dua fonem atau lebih yang mendahului atau mengikuti sebuah vokal dalam satu suku kata. Deretan bunyi [str] pada kata struktur adalah gugus konsonan karena deretan bunyi tersebut terdapat pada suku kata pertama struktur, tetapi deret [k-t] pada kata yang sama bukan gugus konsonan melainkan deret konsonan karena terdapat dalam suku kata yang berbeda, yaitu suku kata pertama [struk-] dan suku kata kedua [-tur]. Contoh di atas adalah gugus tiga konsonan. Contoh berikut adalah gugus dua konsonan, masing-masing pada suku kata pertama: [sta-tis-tik], [tra-di-si], [plas-tik], [dra-ma], [kre-a-tif], [trans-por]. Demikian pula pada kata [bumbu] fonem $/ \mathrm{m} / \mathrm{pada}$ suku kata pertama berderet dengan fonem /b/ pada suku kata kedua.

Selanjutnya, Suku kata adalah bagian kata yang diucapkan dalam satu hembusan napas. Satu kata boleh terdiri atas satu suku kata, misalnya, tas, pak, bus; Dua suku kata, misalnya, toko, bulan, tanah; tiga suku kata, misalnya purnama, setia, kerabat, atau lebih dari tiga suku kata. Kata mandi terdiri atas dua hembusan napas, satu hembusan untuk man- dan satu hembusan untuk - di. Karena itu kata mandi terdiri dari dua suku kata. Suku kata biasanya selalu memiliki vokal yang menjadi puncak suku kata. Puncak itu dapat didahului dan atau diikuti oleh satu konsonan atau lebih. Konsonan atau urutan konsonan apa saja yang mendahului vokal itu disebut tumpu, konsonan atau urutan konsonan apa saja yang mengikuti vokal puncak itu disebut koda. Boleh juga terjadi bahwa satu suku kata hanya terdiri atas satu vokal saja. Kata asa suku kata pertama adalah vokal /a/ saja, yaitu $[a-s a]$.

Ada empat macam jenis suku kata: pertama, suku minimum, yang terdiri atas sebuah vokal sebagai puncak; kedua, tumpu + puncak, yang terdiri atas: sebuah konsonan + puncak, dua buah konsonan + puncak, dan tiga buah konsonan + puncak. Ketiga, puncak + koda: puncak + sebuah konsonan, puncak + dua buah konsonan. Keempat, tumpu + puncak + koda: sebuah konsonan + puncak + koda, dua buah konsonan + puncak + koda, tiga buah konsonan + puncak + koda, tumpu + puncak + sebuah konsonan, tumpu + puncak + dua buah konsonan, tumpu + puncak + tiga buah konsonan. 


\section{METODE PENELITIAN}

Fonemik BDM adalah bagian dari unsur-unsur bahasa yang akan diteliti keberadaannya di dalam BDM sebagaimana adanya digunakan penuturnya pada saat penelitian ini dilakukan. Oleh karena itu, metode penelitian ini adalah metode deskriptif yang bersifat kualitatif.

Data ialah hubungan antara objek penelitian dan konteks objek penelitian (Sudaryanto, 1993; Mahsun, 2007). Objek penelitian ini ialah fonemfonem dan suku kata BDM, sedangkan konteks objek penelitian ini adalah unsur bahasa yang terdapat dalam penggunaan bahasa. Oleh karena itu, data penelitian ini adalah kata-kata yang terdapat di dalam pemakaian BDM yang bersumber dari penutur asli (informan). Syarat informan penelitian ini ialah penutur asli BDM, sudah dewasa, fasih menggunakan bahasa ini, alat-alat ucap tidak terganggu, tidak sedang sakit, bertempat tinggal di tempat yang mayoritas penduduknya Dayak Mali, dan dapat berbahasa Indonesia.

Teknik pengumpulan data dalam penelitian ini sesuai dengan yang terdapat dalam Mahsun, (2007), yaitu teknik cakap semuka. Pada pelaksanaan teknik cakap semuka peneliti langsung melakukan percakapan dengan pengguna bahasa (informan) dengan bersumber pada pancingan yang sudah disiapkan (daftar tanya). Data yang diperoleh menurut permasalahan dan teori yang terdapat dalam penelitian ini, selanjutnya dianalisis berdasarkan urutan-urutan permasalahan dengan menerapkan teknik padan ekstralingual (Mahsun, 2007), yaitu menggunakan unsur ekstralingual (alat-alat ucap) yang digunakan untuk mengelompokkan bunyibunyi suatu bahasa.

\section{HASIL DAN PEMBAHASAN PENELITIAN Vokal BDM}

Berdasarkan ciri-ciri pembeda vokal, dalam BDM terdapat vokal sebagai berikut. Fonem /i/. Fonem /i/ adalah vokal tinggi-depan dengan kedua bibir agak terentang ke samping. Contoh: /itey/ iteng 'datang' (52), /kinah/ kinah 'jatuh' (100), /a vi/ari 'hari' (686).

Fonem /u/. Fonem /u/ adalah vokal tinggibelakang, dengan kedua bibir agak maju dan agak membundar. Contoh: /udah/ udah 'banyak' (18), /bubutn/ bubutn 'ubun-ubun' (251), /kintu/ kintu 'kanan' (107)

Fonem /e/. Fonem /e/ adalah vokal sedangdepan, dengan bentuk bibir netral. Contoh: /ecer/ ecek 'kotor' (115), /jeket/ jaket 'dekat (55), /ate/ ate 'hati' (81)

Fonem /o/. Fonem /o/ adalah vokal sedangbelakang, dengan bentuk bibir kurang bundar. Contoh: /oyo?/ oyok 'anjing'(07), /yapoky/ ngapokng' mengapung' (10), /bonto/ bonto 'buruk' (42)

Fonem /a/. Fonem /a/ adalah vokal rendahtengah, dengan kedua bibir terbuka lebar. Contoh: /ano/ ango 'panjang' (150)/uyat/ urat 'akar' (03), /belana/ belana 'orang' (148). Berdasarkan data-data tersebut di atas dan dihubungkan dengan bagian lidah, posisi lidah, dan bentuk bibir ketika melafalkan vokal, didapati lima buah vokal dalam BDM, yang dapat digambarkan dalam bagan sebagai berikut:

Tabel 1. Vokal Bahasa Dayak Mali

\begin{tabular}{cccc}
\hline $\begin{array}{c}\text { Bagian lidah } \\
\text { Posisi lidah }\end{array}$ & Depan & Tengah & Belakang \\
\hline Tinggi & $\mathrm{i}$ & $\mathrm{u}$ \\
\hline Sedang & $\mathrm{e}$ & $\mathrm{o}$ \\
\hline Rendah & & $\mathrm{a}$ & \\
\hline
\end{tabular}

\section{Alofon Vokal dan Distribusi Vokal BDM}

Fonem /i/ mempunyai dua alofon, yaitu [i] dan [1]. Fonem /i/ dilafalkan [i] jika terdapat pada (1) suku kata terbuka, atau (2) suku kata tertutup yang berakhir dengan fonem $/ \mathrm{m} /, / \mathrm{n} /$, atau $/ \mathrm{y} /$ dan mendapat aksen (tekanan) yang lebih berat daripada suku kata yang lain. Distribusi fonem /i/ terdapat di awal, tengah, dan akhir kata. Contoh:

Suku terbuka: [iten] iteng 'datang' $(52)$, [ikatn] ikan 'ikan' (92), [ayi] ari 'hari' (686). Suku tertutup: [pitn] pitn 'air' (02), [gurikn] gurikng 'baring' (19), [dinikn] dinikng 'dinding' (329) 
Fonem /i/ dilafalkan [I] jika terdapat pada suku kata tertutup dan tanpa aksen yang lebih berat daripada suku lain. Contoh: [baIt] bait baik' (15), [banIh] banih 'benih' (27) [sikIt] sikit 'sedikit' (168).

Fonem /e/ hanya mempunyai satu alofon, yaitu [e]. Alofon itu terdapat pada suku kata terbuka maupun tertutup. Distribusi fonem /e/ terdapat di awal, tengah, dan akhir kata. Contoh: [ece?] ecek 'kotor' (115), [rema] rema 'lima' (130) [ykumes] ngkumes 'bunuh' (40), Fonem /u/ hanya mempunyai satu alofon, yaitu [u]. Alofon itu terdapat pada suku kata terbuka maupun tertutup. Fonem /u/ dapat menempati posisi awal, tengah dan akhir kata. Contoh: [uyat] urat 'akar' (03), [munuk] munuk 'cium' (46), [kintu] kintu 'kanan' (107)
Fonem /a/ hanya mempunyai satu alofon, yaitu [a]. Alofon itu terdapat pada suku kata terbuka maupun tertutup. Fonem /a/ dapat menempati posisi awal, tengah dan akhir kata. Contoh: [abe?] abek 'angin' (06), [liak] liak 'jahe' (521), [kiba] kiba 'kiri' (114)

Fonem /o/ mempunyai dua alofon, yaitu [o] dan [O]. Fonem /o/ dilafalkan /o/ jika terdapat pada suku kata terbuka. Fonem /o/ dilafalkan [O] jika terdapat pada suku tertutup atau suku terbuka yang diikuti oleh suku yang mengandung [O]. Distribusi fonem /o/ terdapat di awal, tengah, dan akhir kata. Contoh: [bido] bido 'tikar' (439), [1OmO?] lomo 'gemuk' (793), [OyO?] oyok 'anjing' (07)

Secara singkat vokal dalam BDM ada yang memiliki satu alofon dan ada yang memiliki dua alofon. Secara singkat dapat digambarkan sebagai berikut.

Tabel 2. Vokal dan Alofon Vokal dalam Bahasa Dayak Mali

\begin{tabular}{|c|c|c|}
\hline Fonem & Alofon & Contoh \\
\hline \multirow[t]{2}{*}{ /i/ } & [i] & [iten]; [guүikn]; \\
\hline & [I] & [[baIt $] ;$ [sikIt $]$ \\
\hline$/ \mathrm{e} /$ & [e] & [ece?]; [keyine] \\
\hline$/ \mathbf{u} /$ & {$[\mathrm{u}]$} & [uүat]; [munuk] \\
\hline \multirow[t]{2}{*}{ /o/ } & [O] & [[bOsOh]; [1OmO?] \\
\hline & [o] & [bido]; [bodo] \\
\hline /a/ & [a] & [abe?]; [lamat] \\
\hline
\end{tabular}

Diftong. Di dalam BDM terdapat tiga buah diftong, iaitu [ei], [ai], dan [au]. Kedua huruf vokal itu melambangkan satu bunyi vokal yang tidak dapat dipisahkan. Pemakaian kata-kata yang mengandung vokal rangkap itu dapat ditunjukkan dalam kata-kata berikut ini. Diftong [ei] dilambangkan secara fonemis /ey/. Contoh: /petey/ [petey] petei 'petai' (546), /amey/ [amey] amei 'senja' (725), Diftong [ai] dilambangkan secara fonemis /ay/. Contoh: /rankay/ [raykay] rangkai 'kering' (113), /naray/ [nayay] narai 'lelaki' (125), Diftong [au] dilambangkan secara fonemis /aw/. Contoh: /peraw/ [peyaw] perau 'sampan' (429), /ikatn belaw/ [ikatn belaw] ikatn belau 'ikan gabus' (571)

Deret Vokal. Apabila di dalam sebuah kata terdapat dua buah vokal secara berurutan dan masing-masing vokal itu mempunyai hembusan napas yang berbeda maka keadaan kedua vokal seperti itu disebut deret vokal. Berbeda dari diftong yang terdapat dalam satu suku kata, kedua vokal dalam deret vokal terdapat pada dua suku kata yang berbeda. Dalam BDM terdapat deret vokal sebagai berikut. /i a/ /di-atn/ diatn 'durian' (518), /i u/ /tiuy/ tiung 'terong' (560), /i o/ /di-o/ dio 'rumah' (361), /a i/ /ka-il/ kail 'kail' (401), /a u/ /a-ur/ aur 'bambu' (500) /a o/ /teja-o?/ tengaok 'ambil' (917), /u e//tu-en/ tuen 'luka'(753), /u a/ /tu-a?/ tuak 'abang ayah' (267). Dengan demikian fonem vokal yang dapat berderet dalam BDM adalah /i a/, /i u/, i o/, /a i/, /a u/, /a o/, /u e/, dan /u a/.

Konsonan BDM. Berdasarkan ciri-ciri pembeda, konsonan dalam BDM dapat diuraikan sebagai berikut: Konsonan hambat bilabial tak bersuara:/p/: /putuy/ putung 'perut' (156), /jipe/ jipe 'gigi' (75), /ykudip/ ngkudip 'menyala' (969). Konsonan hambat bilabial bersuara: /b/: /bonto/ bonto 'buruk' (42), /kubes/ kubes 'mati'(139). Konsonan hambat alveolar tak bersuara: /t/: /tege?/ tegek 'leher' (124), /tiri/ tiri 'tali' (179), /anot/ angot 'muda' (819). Konsonan hambat alveolar bersuara: 
/d/, /dayak/ dayak 'darah' (51), /udip/ udip 'hidup' (83). onsonan hambat palatal tak bersuara: /Í/ /Íawatn/ cawatn 'cangkir' (383), /ñoĺol/ nyocol 'bakar' (16).. Konsonan hambat palatal bersuara: /j/ /jipe/ jipe 'gigi' (75), /ujatn/ ujatn 'hujan' (690). Konsonan hambat velar tak bersuara: /k/, /kaja?/ kajak 'kaki' (103) /munuk/ munuk 'cium' (46). Konsonan h ambat velar bersuara: /g/ /guti?/ gutik 'kutu' (119), /tege?/ tegek 'lahir' (304). Konsonan hambat glotal bersuara: /2/, /abe?/ abek 'angin' (06), loyo?/ oyok 'anjing' (07). Konsonan frikatif apikoalveolar tak bersuara: /s/, /sumit/ sumit 'kumis' (228), /disah/ disah 'turun' (1011), /kubes/ kubes 'mati' (139). Konsonan frikatif glotallfaringal tak bersuara: /h/: /hemat/ hemat 'hemat' (797) /sehat/ sehat 'sihat' (842) /kinah/ kinah 'jatuh' (100). Konsonan nasal bilabial bersuara: /m/: /manuk/ manuk 'burung' (43) /empat/ empat 'empat' (69) /bayem/ barem 'hitam' (86). Konsonan nasal apikoalveolar bersuara: /n/, /nayai/ narai 'lelaki' (125) /bonto/ bonto 'buruk' (42), /duen/ duen 'daun' (53). Konsonan nasal laminopalatal bersuara: $/ \tilde{n} /$, /ñoĺol/ nyocol 'bakar' (16), /iñe?/ inyek 'satu' (165). Konsonan nasal dorsovelar bersuara: /y/, /nayi/ ngari 'siang' (171), /minkan/ mingkan 'beri' (30), /iten/ iteng datang' (52). Konsonan getar (tril) apikoalveolar bersuara: /r/, / yata?/ ratak 'lidah' (128), /buyan/ buran 'bulan' (37) /pasey/ paser 'pasir' (151). Konsonan lateral laminoalveolar: /1/; /liuy/ liur 'ludah' (131), /belayek/ belayek/ 'mereka' (141), /tabal/ tabal 'tebal' (183), Semivokal bilabial bersuara: /w/, /suwe?/ suwek 'istri' (95), /kawai/ kawai 'bahu' (203). Semivokal laminopalatal: /y/ /nayo/ ngayo 'garuk' (73), /uyuy/ uyung 'ayam betina' (582). Dalam BDM fonem konsonan ditemukan sembilan belas buah dan dapat digambarkan sebagai berikut:

Tabel 3. Konsonan dalam Bahasa Dayak Mali

\begin{tabular}{|c|c|c|c|c|c|c|}
\hline $\begin{array}{c}\text { Titik } \\
\text { Artikulasi } \\
\text { Cara } \\
\text { Artikulasi }\end{array}$ & Bilabial & $\begin{array}{l}\text { Labio- } \\
\text { Dental }\end{array}$ & $\begin{array}{l}\text { Apiko- } \\
\text { Dental/ } \\
\text { Alveolar }\end{array}$ & $\begin{array}{c}\text { Lamino- } \\
\text { Palatal }\end{array}$ & $\begin{array}{l}\text { Dorso- } \\
\text { Velar }\end{array}$ & $\begin{array}{c}\text { Glotal/ } \\
\text { Hamzah/ } \\
\text { Faringal }\end{array}$ \\
\hline Hambat: & & & & & & \\
\hline Tak bersuara & $\mathrm{p}$ & & $\mathrm{t}$ & Í & $\mathrm{k}$ & $?$ \\
\hline Bersuara & $\mathrm{b}$ & & d & $\mathrm{j}$ & $\mathrm{g}$ & \\
\hline $\begin{array}{c}\text { Frikatif: } \\
\text { Tak bersuara } \\
\text { Bersuara }\end{array}$ & & & $\mathrm{s}$ & & & $\mathrm{h}$ \\
\hline $\begin{array}{l}\text { Nasal: } \\
\text { Bersuara }\end{array}$ & $\mathrm{m}$ & & $\mathrm{n}$ & $\tilde{\mathrm{n}}$ & $\eta$ & \\
\hline $\begin{array}{c}\text { Getar/Tril: } \\
\text { Bersuara }\end{array}$ & & & $\gamma$ & & & \\
\hline $\begin{array}{l}\text { Lateral: } \\
\text { Bersuara }\end{array}$ & & & 1 & & & \\
\hline $\begin{array}{c}\text { Semivokal: } \\
\text { Bersuara }\end{array}$ & $\mathrm{W}$ & & & $\mathrm{y}$ & & \\
\hline
\end{tabular}

Alofon Konsonan dan Distribusi Konsonan. Posisi (distribusi) fonem konsonan dalam kata atau suku kata dapat menimbulkan terjadinya alofon konsonan. Bagi konsonan hambat, dapat menimbulkan dua alofon, yaitu terbuka (eksplosif) apabila terletak pada awal suku kata dan alofon tertutup (implosif) apabila terletak pada akhir suku kata. Contoh alofon konsonan dalam BDM.
Fonem /p/ mempunyai dua alofon, yaitu [p] terbuka (eksplosif), artinya ketika melafalkannya bibir atas dan bibir bawah terbuka dan sebaliknya [p'] tertutup (implosif), artinya ketika melafalkannya kedua bibir tertutup. Fonem [p] terbuka terdapat pada awal suku, sedangkan [p'] tertutup terdapat pada akhir suku. Fonem /p/ terdapat dalam posisi di awal, tengah, dan di akhir kata. Contoh: [jipe] jipe 'gigi' 
(75), [ñuep'] nyuep ‘suap' (992), [ykudip'] ngkudip 'menyala' (969)

Fonem /b/ hanya mempunyai satu alofon [b] dan posisinya di awal dan di tengah kata dan hanya pada awal suku kata. Contoh: [buyan] buran 'bulan' (37), [kubes] kubes 'mati' (139) Sama dengan fonem $/ \mathrm{p} /$, fonem $/ \mathrm{t} /$ mempunyai dua alofon: $[\mathrm{t}] \mathrm{dan}$ [t']. Alofon [t] ialah alofon terbuka terdapat pada awal kata atau awal suku kata, sedangkan [t'] ialah alofon tertutup terdapat pada akhir suku kata, atau akhir kata. Fonem /t/ dapat menempati posisi awal, tengah, dan akhir kata. Contoh: [tiri] tiri 'tali' (179), [kintu] kintu 'kanan' (107), [nijet'] ninget 'lihat' (129)

Fonem /d/ hanya mempunyai satu alofon [d] yang terdapat pada awal dan tengah kata dan hanya terdapat pada awal suku kata. Contoh: [didi?] didik 'gusi' (215), [udip'] udip 'hidup' (83)

Fonem /k/ mempunyai dua alofon: alofon terbuka [k] dan alofon tertutup [k']. alofon [k] terdapat pada awal suku kata di awal kata atau tengah kata, sedangkan [k'] terdapat pada akhir suku kata. Contoh: [kaja?] kajak 'kaki' (103), [iko?] ikok 'ekor' (68), [siyek'] siek 'garam' (72)

Fonem /g/ hanya mempunyai satu alofon, yaitu [g] yang terdapat pada awal dan tengah kata, itu pun hanya pada awal suku kata saja. Contoh: [ginan] ginan 'nama' (145) [tege?] tegek 'lahir' (304)

Fonem / / / hanya mempunyai satu alofon, yaitu [?] yang terdapat pada akhir suku kata. Contoh: [sodo?] sodok 'dada' (209) didi?] gusi 'gusi' (216)

Fonem /Í/ mempunyai satu alofon, yaitu [í] yang terdapat pada awal dan tengah kata dan hanya di awal suku kata. Contoh: [Íelep] celep ‘sejuk' (723) [ñoĺol] nyocol 'bakar' (16)

Fonem /j/ mempunyai satu alofon, yaitu [j] yang terdapat pada awal suku kata, baik di awal kata maupun di tengah kata. Contoh: [jipe] jipe 'gigi' (75) [kaja?] kajak 'kaki' (103)

Fonem /s/ mempunyai satu alofon, yaitu [s] yang terdapat pada awal dan akhir suku kata dan posisinya di dalam kata menempati awal, tengah, dan akhir. Contoh: [sumit] sumit 'kumis' (228), [kelinset] kelinset 'ikat kepala' (890), [kubes] kubes 'mati' (139)

Fonem /h/ mempunyai satu alofon, yaitu [h] yang terdapat pada awal, dan akhir suku kata dan posisinya terdapat pada awal, tengah, dan akhir kata. Contoh: [hemat] hemat "hemat" (797) [sehatsehat 'sihat' (842), [kinah] kinah 'jatuh' (100)
Fonem /m/ mempunyai satu alofon, yaitu [m] yang terdapat pada awal atau akhir suku kata dan posisinya terdapat pada awal, tengah, dan akhir kata. Contoh: [minkan] mingkan 'beri' (30), [empat]empat 'empat' (69) [bayem] barem 'hitam' (86).

Fonem /n/ mempunyai satu alofon, yaitu [n] yang terdapat pada awal atau akhir suku kata. Posisi fonem $/ \mathrm{n} /$ terdapat pada awal, tengah, dan akhir kata. Contoh: [nayai] narai 'lelaki' (125), [bonto] bonto 'buruk' (42), [duen] duen 'daun' (53),

Fonem / $/$ / mempunyai satu alofon, yaitu [ñ] yang hanya terdapat pada awal suku kata yang terdapat di awal dan di tengah kata. Contoh: [ñolol] nyocol 'bakar' (16), [iñe?] inyek 'satu' (165)

Fonem /y/ mempunyai satu alofon, yaitu [y], yang terdapat pada awal atau akhir suku kata. Di dalam kata dapat menempati posisi di awal, tengah, dan akhir. Contoh: [nusuk] ngusuk 'gosok' (77), [minkan] mingkan 'beri' (30), [duduy] dudung 'hidung' (82)

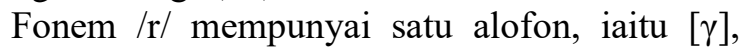
yang terdapat pada awal dan akhir suku kata. Di dalam kata dapat menempati posisi awal, tengah, dan akhir. Contoh: [yata?] ratak 'lidah' (128),

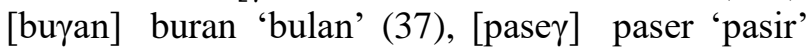
(151),

Fonem /1/ mempunyai satu alofon, yaitu [1] yang terdapat pada awal atau akhir suku kata. Fonem /l/ dapat menempati posisi awal, tengah, dan akhir kata. Contoh: [le $\gamma]$ ler 'licin' (127), [kale?], kalek 'ikan lele' (605), [tompol] tompol 'tumpul' (198),

Fonem /w/ mempunyai satu alofon, yaitu [w]. Pada awal suku kata bunyi [w] berfungsi sebagai konsonan. Di dalam kata, fonem ini dapat menempati posisi tengah dan akhir kata. Contoh: [kawai] kawai 'bahu' (203), [uwi] uwi 'rotan' (554), [belaw] belau 'gabus' (571),

Fonem /y/ mempunyai satu alofon, yaitu [y]. Fonem /y/ dapat menempati posisi tengah kata, yaitu pada awal suku kata dan akhir kata. Contoh: [yayo] ngayo 'garuk' (73), [nayay] narai 'laki-laki' (125). Konsonan yang mempunyai varian atau alofon di dalam bahasa Dayak Mali ialah /p/, /t/, dan /k/ dan masing-masing fonem tersebut mempunyai dua alofon, yaitu: /p/ dua alofon: [p] dan [p']; /t/ dua alofon: [t] dan [t']; dan /k/ dua alofon: [k] dan [k'].

\section{Gugus Konsonan}

Sesuai dengan pernyataan di dalam kerangka teori bahwa deretan dua konsonan atau lebih yang 
terdapat dalam satu suku kata dalam sebuah kata, yang mendahului atau mengikuti vokal disebut gugus konsonan. Di dalam BDM terdapat gugus konsonan sebagaimana tampak dalam data berikut ini.

Gugus sebagai tumpu. $/ \mathrm{mp} /$ [mpadan] mpadang 'alang-alang' (498), /mb/ [mbala] mbaca 'membaca' (921), /nd/ [ndidik] ndidik 'mendidik' (931), /nt/ [ntamu] ntamu 'kunyit' (534), /nÍ/ [nÍaÍlak] ncacak 'cecak' (597), /ns/ [nsulay] nsulang 'kupu-kupu' (624), /yk/ [ykumes], gkumes 'membunuh' (40), /ng/ [ngali] nggali 'menggali' (71), . Gugus sebagai Koda: /pm/ [antapm] antapm 'hantam' (79), /tn/ [ujatn] ujatn 'hujan' (88), /ky/ [guүikn] gurikng 'baring' (19) Gugus konsonan seperti tampak dalam data-data di atas menunjukkan bahwa yang bergugus adalah konsonan yang homorgan. Dalam keadaan seperti itu gugus sebagai tumpu dimulai dengan fonem nasal: $/ \mathrm{mp} /, / \mathrm{mb} /, / \mathrm{nt} /$, $/ \mathrm{nd} /, / \mathrm{nI} /$, /ns/, /nk/, dan $/ \mathrm{ng} /$, sedangkan gugus sebagai koda diakhiri juga dengan nasal: /pm/, /tn/, dan $/ \mathrm{ky} /$. Keadaan seperti ini dapat dikatakan sebagai nasalisasi sealat atau homorgan.

\section{Deret Konsonan}

Deret konsonan merupakan urutan dua konsonan yang terdapat pada sebuah kata dan kedua konsonan tersebut terdapat pada suku kata yang berbeda. Dalam bahasa Dayak Mali, deret konsonan yang tampak melalui data yang diperoleh adalah sebagai berikut. /mp/ [pam-pi] pampi 'pipi' (241), /mb/ [lom-bon] lombong 'lumbung' (349), /nt/ [bon-to] bonto 'buruk' (42), /nd/ [Íen-dol] cendol 'cendol' (448), /nÍ/ [kin-lit] kincit 'menceret' (758), /nj/ [man-jor] manjor 'manjur' (813), /ns/ [yansen] nganseng 'napas' (146), /sk/ [mis-kin] miskin 'miskin' (818), /ys/ [ay-sa] angsa 'angsa' (580), /ng/ [man-ga] mangga 'mangga' (473), /nk [yay-kay] rangkai 'kering' (113), /kt/ [bak-tut] baktut 'lutut' (133), / $\gamma \mathrm{d} /$ [Íey-das] cerdas 'cerdas' (788), $/ \gamma \mathrm{h}$ [ge $\gamma$-hana] gerhana 'gerhana' (682). Fonem-Fonem konsonan yang dapat berderet dalam bahasa Dayak Mali ialah /mp/, /mb/, /nt/, /nd/, /nÍ/, /nj/, /ns/, /sk/, /ys/, /nj/, /nk/, /kt/, / $\gamma \mathrm{d} /$, dan $/ \gamma \mathrm{h} /$.

\section{Suku Kata}

Sesuai kerangka teori dan sesuai dengan data kata-kata dalam BDM, jenis suku kata dalam bahasa Dayak Mali adalah sebagai berikut. Suku minimum, yang terdiri atas sebuah vokal sebagai puncak. Contoh: [a-be?] abe? 'angin' (06), [i-juy] ijuy 'duduk' (67), [ba-u] bau 'baru' (20). Tumpu + puncak: sebuah konsonan + puncak, contoh: [ñoÍol] nyocol 'bakar' (16), [gu- $\gamma$ ikn] gurikng 'baring' (19), [mu-nuk] munuk 'cium' (46), dua buah konsonan + puncak, contoh: [mba-Ía] mbaca 'membaca' (921), [ndi-dik] ndidik 'mendidik' (931), [nta-mu] ntamu 'kunyit' (534. Puncak + koda: puncak + sebuah konsonan, contoh: [ba-it $t$ bait 'baik' (15), [mu-an] muan'sungai' (174), puncak + dua konsonan, contoh: [pint] pint 'air' (02), [antapm] antapm 'hantam' (79). Tumpu + puncak + koda, contoh: [mig-kan] mingkan 'beri' (30), [i-tey] iteng 'datang' (52), [yan-sey] nganseng 'nganseng' (146)

\section{SIMPULAN DAN SARAN \\ Simpulan}

Berdasarkan fakta-fakta mengenai masalah penelitian ini yang diperoleh melalui data-data fonemik BDM sebagaimana dibahas dalam bagian analisis, akhirnya jawaban atas masalah penelitian ini dapat dirumuskan Fonemik BDM dan sekaligus sebagai kesimpulan penelitian ini. (1) Fonem yang terdapat dalam BDM ialah fonem vokal, konsonan, semivokal, dan diftong. Prosodi tidak bersifat fonemis; (2) Fonem-fonem BDM ada yang mempunyai satu alofon, dua alofon dan distribusi fonem-fonem tersebut ada yang dapat menduduki posisi awal, tengah, dan akhir kata; ada yang hanya dapat menduduki posisi awal dan tengah kata; ada yang hanya dapat menduduki posisi tengah dan akhir kata; dan ada yang hanya dapat menduduki posisi akhir kata. Khusus untuk distribusi fonem konsonan, ada konsonan yang dapat menjadi tumpu dan koda dan ada yang hanya menjadi koda; (3) Gugus fonem dalam BDM terdapat sebagai tumpu dan koda, masing-masing gugus dua konsonan. Sebagai tumpu dimulai dengan konsonan nasal dan sebagai koda diakhiri juga dengan nasal. Kedua konsonan tersebut merupakan nasalisasi sealat atau homorgan; (4) Semua vokal bahasa Dayak Mali terdapat dalam kelompok atau deret vokal. Demikian pula dengan konsonan, sesuai dengan sifat-sifat bunyi bahasa yang mempunyai kecenderungan untuk dipengaruhi oleh lingkungannya. Dalam bahasa Dayak Mali terdapat deret konsonan sebagai berikut: /mp/, /mb/, /nt/, /nd/, /nI /, /nj/, /nk/,/ng/. Terbukti juga bahwa fonem dalam bahasa Dayak Mali bersifat simetris, yaitu /p, b, m/; /t, d, n/; /c, j, ñ /; /k, g, y/. Di luar itu terdapat juga deret konsonan: /ns/, /sk/, /ns/, /kt/, $/ \gamma \mathrm{d} /$, dan $/ \gamma \mathrm{h} /$. (5) Suku kata bahasa Dayak Mali terdiri atas empat macam: suku minimum, yaitu 
vokal sebagai puncak; tumpu dan puncak; puncak dan koda; dan tumpu puncak dan koda.

\section{Saran}

Melihat perkembangan zaman yang memiliki roh modernisasi dan perubahan di segala bidang, maka bahasa Dayak Mali pun tak mungkin luput dari perubahan. Perubahan yang sangat mungkin terjadi adalah dalam bidang fonologi, iaitu masuknya sejumlah fonem serapan dari bahasa serumpun atau dari bahasa asing. Seiring dengan itu pula memungkinkan masuknya struktur suku kata yang terdiri atas urutan konsonan (gugus) sebagai tumpu maupun sebagai koda hingga tiga konsonan.Oleh karena itu, untuk menyempurnakan penelitian ini, penelitian berikutnya diharapkan dapat mencari datadata fonemik dari pemakaian bahasa Dayak Mali yang bersifat modern, yaitu bahasa Dayak yang digunakan di dalam forum ilmiah, yang membicarakan berbagai-bagai aspek kehidupan.

\section{DAFTAR RUJUKAN}

Bloomfield, L. 1933. Language. Henry Holt and Co., New York.

Bamba, J. (Ed.). 2008. Mozaik Dayak: Keberagaman Subsuku dan Bahasa Dayak di Kalimantan Barat. Pontianak: Institut Dayakologi.

Chomsky, N. 1964. "Current Issues in Linguistic Theory", The Structure of Language. Jerry A. F. Fodor \& Jerrold J. Katz Eds. PrenticeHall, Inc., Englewood Cliffs, New Jersey.

Crystal, D. 1987. The Cambridge Encyclopedia of Language. New York: Cambridge University Press.
Crystal, D. (2000). Language Death. New York: Cambridge University Press.

http://repository.usu.ac.id/bitstream/handle/123456789 /19560/Appendix.pdf?sequence $=1 \&$ isAllowed $=y$

Keraf, G. 1980. Tata Bahasa Indonesia. Ende: Nusa Indah.

Mahsun. 2007. Metode Penelitian Bahasa: Tahapan Strategi, Metode, dan Tekniknya. Jakarta: Raja Grafindo Persada.

Moeliono, A. 1988. Tata Bahasa Baku Bahasa Indonesia. Jakarta: PN Balai Pustaka.

Parera, J. D. 1988. Fonetik dan Fonemik. Ende: Nusa Indah.

Ramlan, M. 1981. Ilmu Bahasa Indonesia: Sintaksis. Yogyakarta: UP Karyono.

Samsuri. 1985. Analisis Bahasa. Jakarta: Erlangga.

Simanjuntak, H. 2016. Fonemik Bahasa Dayak Kanayatn. Laporan Penelitian: FKIP Universitas Tanjungpura Pontianak.

Simanjuntak, H. 2017. Fonemik Bahasa Dayak Ulu Sakado. Laporan Penelitian: FKIP Universitas Tanjungpura Pontianak.

Simanjuntak, H. 2018. Fonemik Bahasa Dayak Ketungau Sesat. Laporan penelitian: FKIP Universitas Tanjungpura Pontianak.

Sudaryanto. 1993. Metode dan Aneka Teknik Analisis Bahasa: Pengantar Penelitian Wahana Kebudayaan Secara Linguistis. Seri ILDEP, Yogyakarta: Duta Wacana Press.

Verhaar, J.W.M. 1981. Pengantar Linguistik. Yogyakarta: Gadjah Mada University Press. 